DOI $10.31489 / 2020 \mathrm{M} 4 / 26-32$

UDC 517.98

\author{
N.T. Bekbayev ${ }^{1,2, *}$, K.S. Tulenov ${ }^{1,2}$ \\ ${ }^{1}$ Institute of Mathematics and Mathematical Modeling, Almaty, Kazakhstan; \\ ${ }^{2}$ Al-Farabi Kazakh National University, Almaty, Kazakhstan \\ (E-mail: n.bekbaev@mail.ru, tulenov@math.kz)
}

\title{
On boundedness of the Hilbert transform on Marcinkiewicz spaces
}

We study boundedness properties of the classical (singular) Hilbert transform

$$
(\mathcal{H} f)(t)=p \cdot v \cdot \frac{1}{\pi} \int_{\mathbb{R}} \frac{f(s)}{t-s} d s
$$

\begin{abstract}
acting on Marcinkiewicz spaces. The Hilbert transform is a linear operator which arises from the study of boundary values of the real and imaginary parts of analytic functions. Questions involving the $\mathcal{H}$ arise therefore from the utilization of complex methods in Fourier analysis, for example. In particular, the $\mathcal{H}$ plays the crucial role in questions of norm-convergence of Fourier series and Fourier integrals. We consider the problem of what is the least rearrangement-invariant Banach function space $F(\mathbb{R})$ such that $\mathcal{H}$ : $M_{\phi}(\mathbb{R}) \rightarrow F(\mathbb{R})$ is bounded for a fixed Marcinkiewicz space $M_{\phi}(\mathbb{R})$. We also show the existence of optimal rearrangement-invariant Banach function range on Marcinkiewicz spaces. We shall be referring to the space $F(\mathbb{R})$ as the optimal range space for the operator $\mathcal{H}$ restricted to the domain $M_{\phi}(\mathbb{R}) \subseteq \Lambda_{\varphi_{0}}(\mathbb{R})$. Similar constructions have been studied by J.Soria and P.Tradacete for the Hardy and Hardy type operators [1]. We use their ideas to obtain analogues of their some results for the $\mathcal{H}$ on Marcinkiewicz spaces.
\end{abstract}

Keywords: rearrangement-invariant Banach function space, Hilbert transform, Calderón operator, Marcinkiewicz space.

\section{Introduction}

The classical Hilbert transform $\mathcal{H}$ (for measurable functions on $\mathbb{R}$ ) is given by the formula

$$
(\mathcal{H} f)(t)=p \cdot v \cdot \frac{1}{\pi} \int_{\mathbb{R}} \frac{f(s)}{t-s} d s
$$

There is an uncountable number of papers devoted to research of the Hilbert transform defined by the formula (1). In 20th century, David Hilbert finally showed that the function $\sin (\omega t)$ is the Hilbert transform of $\cos (\omega t)$. After that, the Hilbert transform has been studied by many authors in different research areas of science. One of the important applications of the Hilbert transform in Interpolation theory and rearrangement invariant Banach function spaces has received a lot of attention since Boyd's pioneer work in 1966 [2] (see also [3], [4]), which is related to the main objective of this paper. The boundedness properties of some classical operators were studied in [5-8]. Also, the boundedness properties of the Hilbert transform were studied by many authors. For instance, [9], [10], [11] and recent papers [12-16], and references therein.

\footnotetext{
${ }^{*}$ Corresponding author.

E-mail: n.bekbaev@mail.ru
} 


\section{Preliminaries}

Let $(I, m)$, where $I=\mathbb{R}_{+}=(0, \infty)$ (resp. $\left.I=\mathbb{R}\right)$ denote the measure space equipped with Lebesgue measure $m$. Let $L(I, m)$ be the space of all measurable real-valued functions on $I$ equipped with Lebesgue measure $m$ i.e. functions which coinside almost everywhere are considered identical. Define $L_{0}(I, m)$ to be the subset of $L(I, m)$ which consists of all functions $f$ such that $m(\{t:|f(t)|>s\})<\infty$ for some $s>0$. For $f \in L_{0}(I)$ we denote $f^{*}(t)$ the decreasing rearrangement of the function $|f|$. That is,

$$
f^{*}(t)=\inf \{s \geq 0: m(|f|>s) \leq t\}, t>0
$$

Definition 1. [11; 49] A function $\varphi$ defined on the semiaxis $[0, \infty)$ is said to be quasiconcave if

(i) $\varphi(t)=0 \Leftrightarrow t=0$

(ii) $\varphi(t)$ is positive and increasing on $\mathbb{R}_{+}$.

(iii) $\frac{\varphi(t)}{t}$ is decreasing on $\mathbb{R}_{+}$.

Observe that every nonnegative function on $[0, \infty)$ that vanishes at origin is quasiconcave. The reverse, however, is not always true. However, we may replace, if necessary, a quasiconcave function $\varphi$ by its least concave majorant $\widetilde{\varphi}$ such that

$$
\frac{1}{2} \widetilde{\varphi} \leq \varphi \leq \widetilde{\varphi}
$$

(see $[10 ; 71])$.

Definition 2. [10; 59] A Banach function space $E$ is called rearrangement-invariant if, whenever $f$ belongs to $E$ and $g$ is equimeasurable with $f$, then $g$ also belongs to $E$ and $\|f\|_{E}=\|g\|_{E}$.

Next we define the Köthe dual (or associate) space of rearrangement invariant Banach function spaces. Given rearrangement invariant Banach function space $E$ on $I$, equipped with Lebesgue measure $m$ the Köthe dual space $E^{\times}$on $I$ is defined by

$$
E(I)^{\times}=\left\{g \in L_{0}(I): \int_{I}|f(t) g(t)| d t<\infty, \quad \forall f \in E(I)\right\} .
$$

$E^{\times}$is a Banach space with the norm

$$
\|g\|_{E(I) \times}:=\sup \left\{\int_{I}|f(t) g(t)| d t: f \in E(I),\|f\|_{E(I)} \leq 1\right\} .
$$

If $E(I)$ is a rearrangement invariant Banach function space, then $\left(E^{\times}(I),\|\cdot\|_{E^{\times}(I)}\right)$ is also rearrangement invariant Banach function space (cf. [9; Section 2.4]). For more details we refer to [10], [17].

Let $\Omega$ denote the set of increasing concave functions $\varphi:[0, \infty) \rightarrow[0, \infty)$ for which $\lim _{t \rightarrow 0+} \varphi(t)=0$ (or simply $\varphi(+0)=0)$. For the function $\varphi$ in $\Omega$, the Lorentz space $\Lambda_{\varphi}\left(\mathbb{R}_{+}\right)$is defined by setting

$$
\Lambda_{\varphi}\left(\mathbb{R}_{+}\right):=\left\{f \in L_{0}(I): \int_{\mathbb{R}_{+}} f^{*}(s) d \varphi(s)<\infty\right\}
$$

and equipped with the norm

$$
\|f\|_{\Lambda_{\varphi}\left(\mathbb{R}_{+}\right)}:=\int_{\mathbb{R}_{+}} f^{*}(s) d \varphi(s) .
$$

Let $\psi$ be a quasiconcave function on $[0, \infty)$. Define the Marcinkiewicz space $M_{\psi}(I)$ by setting 


$$
M_{\psi}(I):=\left\{f \in L_{0}(I):\|f\|_{M_{\psi}\left(\mathbb{R}_{+}\right)}<\infty\right\}
$$

equipped with the norm

$$
\|f\|_{M_{\psi}\left(\mathbb{R}_{+}\right)}:=\sup _{t>0} \frac{t}{\psi(t)} \int_{0}^{t} f^{*}(s) d s .
$$

These spaces are examples of rearrangement invariant Banach function space. For more information we refer [10], [11]. For more information we refer [10], [11]. The space $\left(L_{1}+L_{\infty}\right)\left(\mathbb{R}_{+}\right)=L_{1}\left(\mathbb{R}_{+}\right)+$ $L_{\infty}\left(\mathbb{R}_{+}\right)$consists of functions which are sums of bounded measurable and summable functions $f \in$ $L_{0}\left(\mathbb{R}_{+}\right)$equipped with the norm given by

$$
\|f\|_{\left(L_{1}+L_{\infty}\right)\left(\mathbb{R}_{+}\right)}=\inf \left\{\left\|f_{1}\right\|_{L_{1}\left(\mathbb{R}_{+}\right)}+\left\|f_{2}\right\|_{L_{\infty}\left(\mathbb{R}_{+}\right)}: f=f_{1}+f_{2}, f_{1} \in L_{1}\left(\mathbb{R}_{+}\right), f_{2} \in L_{\infty}\left(\mathbb{R}_{+}\right)\right\}
$$

Define

$$
\varphi_{0}(t)= \begin{cases}t \log \left(\frac{e^{2}}{t}\right), & 0<t \leq 1 \\ 2 \log (e t), & 1 \leq t<\infty .\end{cases}
$$

It is easy to show that $\varphi_{0}$ is a quasi-concave function on $[0, \infty)$. It was proved in $[13 ; 5]$ that $\Lambda_{\varphi_{0}}\left(\mathbb{R}_{+}\right)$is the maximal rearrangement invariant Banach function space such that $S: \Lambda_{\varphi_{0}}\left(\mathbb{R}_{+}\right) \rightarrow\left(L_{1}+L_{\infty}\right)\left(\mathbb{R}_{+}\right)$ is bounded. For a function $f \in \Lambda_{\varphi_{0}}\left(\mathbb{R}_{+}\right)$define the Calderón operator $S: \Lambda_{\varphi_{0}}\left(\mathbb{R}_{+}\right) \rightarrow\left(L_{1}+L_{\infty}\right)\left(\mathbb{R}_{+}\right)$ as follows

$$
(S f)(t):=\frac{1}{t} \int_{0}^{t} f(s) d s+\int_{t}^{\infty} \frac{f(s)}{s} d s, t>0 .
$$

Similarly, for a function $f \in \Lambda_{\varphi_{0}}(\mathbb{R})$, define the Hilbert transform as follows

$$
(\mathcal{H} f)(t)=p \cdot v \cdot \frac{1}{\pi} \int_{\mathbb{R}} \frac{f(s)}{t-s} d s .
$$

For more details on these operators refer to [10], [11].

\section{Main results}

More general results for the Hilbert transform in quasi-Banach rearrangement invariant spaces were obtained in [12], [13]. In this work, we study the boundedness of the Hilbert transform on Marcinkiewicz spaces. The following is the main result of this paper.

Theorem 1. Let $\phi$ be an increasing concave function on $[0, \infty)$ such that $\phi(0)=0$ and

$$
\lim _{s \rightarrow \infty} \frac{\phi(s)}{s}=0, \lim _{s \rightarrow 0} \phi(s) \log \left(\frac{e}{s}\right)=0 .
$$

Then

$$
S: M_{\phi}\left(\mathbb{R}_{+}\right) \rightarrow\left(L_{1}+L_{\infty}\right)\left(\mathbb{R}_{+}\right)
$$

is bounded if and only if

$$
t S\left(\frac{\phi(t)}{t}\right)<\infty, \forall t>0
$$

Proof. Let

$$
S: M_{\phi}\left(\mathbb{R}_{+}\right) \rightarrow\left(L_{1}+L_{\infty}\right)\left(\mathbb{R}_{+}\right)
$$


Since $S$ is positive, it follows from Proposition $1.3 .5[18 ; 27]$ that $S: M_{\phi}\left(\mathbb{R}_{+}\right) \rightarrow\left(L_{1}+L_{\infty}\right)\left(\mathbb{R}_{+}\right)$is bounded. Then by duality and since $S=S^{*}$ (see Lemma 6 [14]), it follows that

$$
S:\left(L_{1}+L_{\infty}\right)^{\times}\left(\mathbb{R}_{+}\right) \rightarrow M_{\phi}^{\times}\left(\mathbb{R}_{+}\right)
$$

is bounded. However, $\left(L_{1}+L_{\infty}\right)^{\times}\left(\mathbb{R}_{+}\right)=\left(L_{1} \cap L_{\infty}\right)\left(\mathbb{R}_{+}\right)$and $M_{\phi}^{\times}\left(\mathbb{R}_{+}\right)=\Lambda_{\phi}\left(\mathbb{R}_{+}\right)$(see [10], [11]). Hence,

$$
S:\left(L_{1} \cap L_{\infty}\right)\left(\mathbb{R}_{+}\right) \rightarrow \Lambda_{\phi}\left(\mathbb{R}_{+}\right)
$$

is bounded.

Take $f=\chi_{(0, t)}$ and it is easy to show that $\chi_{(0, t)} \in\left(L_{1} \cap L_{\infty}\right)\left(\mathbb{R}_{+}\right)$for any $t>0$. Therefore, it follows from (4) that $S \chi_{(0, t)} \in \Lambda_{\phi}\left(\mathbb{R}_{+}\right)$, that is,

$$
\left\|S \chi_{(0, t)}\right\|_{\Lambda_{\phi}\left(\mathbb{R}_{+}\right)}<\infty .
$$

But, the latter condition (5) is equivalent to $t S\left(\frac{\phi(t)}{t}\right)<\infty$ for any $t>0$.

Indeed,

$$
\begin{aligned}
\left\|S \chi_{(0, t)}\right\|_{\Lambda_{\phi}\left(\mathbb{R}_{+}\right)} & =\int_{0}^{\infty} S \chi_{(0, t)}(s) d \phi(s)=\int_{0}^{t}\left(1+\log \left(\frac{t}{s}\right)\right) d \phi(s)+\int_{t}^{\infty} \frac{t}{s} d \phi(s) \\
& =\left.\left(\phi(s) \log \left(e \frac{t}{s}\right)\right)\right|_{0} ^{t}+\int_{0}^{t} \frac{\phi(s)}{s} d s+\left.t \frac{\phi(s)}{s}\right|_{t} ^{\infty}+t \int_{t}^{\infty} \frac{\phi(s)}{s^{2}} d s \\
& =t \cdot S\left(\frac{\phi(t)}{t}\right)+t \lim _{s \rightarrow \infty} \frac{\phi(s)}{s}-\lim _{s \rightarrow 0} \log \left(e \frac{t}{s}\right) .
\end{aligned}
$$

Taking the assumptions (3) into account, we obtain the desired result.

Conversely, if $t S\left(\frac{\phi(t)}{t}\right)<\infty$, then, as we proved above, we have $\left\|S \chi_{(0, t)}\right\|_{\Lambda_{\phi}\left(\mathbb{R}_{+}\right)}<\infty$.

Let us show that $S: M_{\phi}\left(\mathbb{R}_{+}\right) \rightarrow\left(L_{1}+L_{\infty}\right)\left(\mathbb{R}_{+}\right)$is bounded.

Take $f \in M_{\phi}\left(\mathbb{R}_{+}\right)$. Then by formula $(6.8)$ in $[10 ; 76]$ and Hölder inequality (see $[10 ; 9]$ )

$$
\begin{aligned}
\|S f\|_{L_{1}+L_{\infty}\left(\mathbb{R}_{+}\right)} & =\int_{0}^{1}(S f)^{*}(s) d s \leq \int_{0}^{1}\left(S f^{*}\right)(s) d s=\int_{0}^{\infty}\left(S f^{*}\right)(s) \chi_{(0,1)}(s) d s \\
& =\int_{0}^{\infty} f^{*}(s) S \chi_{(0,1)}(s) d s \leq\|f\|_{M_{\phi}\left(\mathbb{R}_{+}\right)}\left\|S \chi_{(0,1)}\right\|_{M_{\phi}^{\times}\left(\mathbb{R}_{+}\right)} \\
& =\|f\|_{M_{\phi}\left(\mathbb{R}_{+}\right)}\left\|S \chi_{(0,1)}\right\|_{\Lambda_{\phi}\left(\mathbb{R}_{+}\right) .}
\end{aligned}
$$

Since $f$ is arbitrary and $\left\|S \chi_{(0,1)}\right\|_{\Lambda_{\phi}\left(\mathbb{R}_{+}\right)}<\infty$, the assertion follows.

Corollary 1. Let the assumptions of Theorem 1 hold. If $M_{\phi}\left(\mathbb{R}_{+}\right) \subset \Lambda_{\varphi_{0}}\left(\mathbb{R}_{+}\right)$, where $\varphi_{0}$ defined by (2), then there is a minimal rearrangement invariant Banach function space $F\left(\mathbb{R}_{+}\right)$such that

$$
S: M_{\phi}\left(\mathbb{R}_{+}\right) \rightarrow F\left(\mathbb{R}_{+}\right)
$$

is bounded.

Proof. By Theorem 1,

$$
S: M_{\phi}\left(\mathbb{R}_{+}\right) \rightarrow\left(L_{1}+L_{\infty}\right)\left(\mathbb{R}_{+}\right)
$$

is bounded if and only if $t S\left(\frac{\phi(t)}{t}\right)<\infty$ for any $t>0$. As it was proved in Theorem 1, the latter condition is equivalent to $S \chi_{(0, t)} \in \Lambda_{\phi}\left(\mathbb{R}_{+}\right)$. Since $S=S^{*}$ and $\Lambda_{\phi}^{\times}\left(\mathbb{R}_{+}\right)=M_{\phi}\left(\mathbb{R}_{+}\right)$, it follows from 
Proposition $3.9[1 ; 876]$ that there is a minimal rearrangement invariant Banach function space $F\left(\mathbb{R}_{+}\right)$ such that

$$
S: M_{\phi}\left(\mathbb{R}_{+}\right) \rightarrow F\left(\mathbb{R}_{+}\right)
$$

is bounded.

Corollary 2. Let the assumptions of Corollary 1 hold. Then there is a minimal rearrangement invariant Banach function space $F(\mathbb{R})$ such that the Hilbert transform

$$
\mathcal{H}: M_{\phi}(\mathbb{R}) \rightarrow F(\mathbb{R})
$$

is bounded.

Proof. By Corollary 1, there is a rearrangement invariant Banach function space $F\left(\mathbb{R}_{+}\right)$such that $S: M_{\phi}\left(\mathbb{R}_{+}\right) \rightarrow F\left(\mathbb{R}_{+}\right)$is bounded. Hence, by Theorem $4.8[10 ; 138], \mathcal{H}: M_{\phi}(\mathbb{R}) \rightarrow F(\mathbb{R})$ is bounded. By assumming that $G(\mathbb{R})$ is another rearrangement invariant Banach function space such that $\mathcal{H}$ : $M_{\phi}(\mathbb{R}) \rightarrow G(\mathbb{R})$ is bounded. Take $f \in M_{\phi}(\mathbb{R})$. Then $f^{*} \in M_{\phi}\left(\mathbb{R}_{+}\right)$. By $[13$, Lemma 5$]$ there is a function $g \in M_{\phi}(\mathbb{R})$ with $f^{*}=g^{*}$ such that $S f^{*}(t) \leq c_{a b s}(\mathcal{H} g)^{*}(t), t>0$, which shows $S f^{*} \in G\left(\mathbb{R}_{+}\right)$. Since $f \in M_{\phi}(\mathbb{R})$ is arbitrary, it follows from the Corrollary 1 that $M_{\phi}\left(\mathbb{R}_{+}\right) \subset G\left(\mathbb{R}_{+}\right)$, i.e. $M_{\phi}(\mathbb{R}) \subset G(\mathbb{R})$.

This completes the proof.

\section{Acknowledgments}

This work was partially supported by the Science Committee of the Ministry of Education and Science of the Republic of Kazakhstan, project no. AP08052004.

\section{References}

1 Soria J., Tradacete, P. (2016). Optimal rearrangement invariant range for Hardy-type operators. Proc. of the Royal Soc. of Edinburgh. 146A, 865-893.

2 Boyd, D. (1966). The Hilbert transformation on rearrangement-invariant Banach spaces. Thesis, University of Toronto.

3 Boyd, D. (1967). The Hilbert transform on rearrangement-invariant spaces. Can. J. Math. 19, 599-616.

4 Boyd, D. (1969). Indices of function spaces and their relationship to interpolation. Can. J. Math. $38,1245-1254$.

5 Buriankova, E., Edmunds, D., Pick, L. (2017). Optimal function spaces for the Laplace transform. Rev.Mat.Complut. Vol.30, № 3., 451-465.

6 Carro, M., Orliz-Caballo, C. (2015). Boundedness of integral operators on decreasing functions. Proceedings of the Royal Society of Edinburgh Section A: Mathematics, Vol.145, № 4, 725-744.

7 Musil, V., Ol'hava, L. (2019). Interpolation theorem for Marcinkiewicz spaces with applications to Lorentz gamma spaces. Math. Nachr., Vol.292, № 5, 1106-1125.

8 Mastylo, M., Pe'rez, C. (2012). The hardy-littlewood maximal type operators between banach function spaces. Indiana University Mathematics Journal, Vol.61, № 3, 883-900.

9 Bennett, C. (1975). A Hausdorff-Young theorem for rearrangement invariant spaces. Pacific J. Math. 47, 311-328.

10 Bennett, C., Sharpley, R. (1988). Interpolation of Operators / Pure and Applied Mathematics, AP, South Carolina.

11 Krein, S., Petunin, Y., Semenov, E. (1982). Interpolation of linear operators. Amer. Math. Soc., Providence, R.I. 
12 Sukochev, F., Tulenov, K., Zanin, D. (2019). The optimal range of the Calderón operator and its applications. J. Funct. Anal. 277, № 10., 3513-3559.

13 Sukochev F., Tulenov, K., Zanin, D. (2019). The boundedness of the Hilbert transformation from one rearrangement invariant Banach space into another and applications. arXiv:1909.10897, 117.

14 Tulenov, K. (2020). Optimal Rearrangement-Invariant Banach function range for the Hilbert transform. Eurasian Math. Journal. (In Press)

15 Edmunds, D., Mihula, Z., Musil, V., Pick, L. (2020). Boundedness of classical operators on rearrangement-invariant spaces. J. Funct. Anal. 278, № 4., 1-56.

16 Agora, E., Carro, M., Soria, J. (2012). Boundedness of the Hilbert transform on weighted Lorentz spaces. J. Math. Anal. Appl. 395, № 1., 218-229.

17 Lindenstrauss, J., Tzafiri, L. (1979). Classical Banach spaces. Springer-Verlag, II.

18 Meyer-Nieberg, P. (1991). Banach Lattices. Springer-Verlag.

Н.Т. Бекбаев, Қ.С. Төленов

\section{Марцинкевич кеңістіктеріндегі Гильберт түрлендіруінің шенелгендігі туралы}

Мақалада Марцинкевич кеңістіктеріндегі функцияларға әсер ететін

$$
(\mathcal{H} f)(t)=p \cdot v \cdot \frac{1}{\pi} \int_{\mathbb{R}} \frac{f(s)}{t-s} d s
$$

классикалық (сингулярлық) Гильберт түрлендіруінің шенелгендік қасиеттері зерттелді. Гильберт түрлендіруі аналитикалық функциялардың нақты және жорамал бөліктерінің шекаралық мәндерін зерттеу кезінде туындайтын сызықтық оператор болып табылады. Сондықтан $\mathcal{H}$ түрлендіруіне қатысты сұрақтар Фурье талдауының күрделі әдістерін қолданғанда пайда болады. Дербес жағдайда $\mathcal{H}$ түрлендіруі Фурье қатарлары мен Фурье интегралдарының норма бойынша жинақталуының мәселесінде шешуші рөл атқарады. Мақала авторлары бекітілген $M_{\phi}(\mathbb{R})$ Марцинкевич кеңістігі үшін $\mathcal{H}: M_{\phi}(\mathbb{R}) \rightarrow F(\mathbb{R})$ түрлендіруі шенелген болатындай ең кіші $F(\mathbb{R})$ алмастыру-инвариантты банах функциялар кеңістігі қандай болатыны туралы есепті қарастырды. Сонымен қатар, Марцинкевич кеңістіктерінде тиімді алмастыру-инвариантты банах функциялар жиыны бар болатынын көрсетті және $F(\mathbb{R})$ кеңістігі $M_{\phi}(\mathbb{R}) \subseteq \Lambda_{\varphi_{0}}(\mathbb{R})$ кеңістігіндегі Гильберт түрлендіруінің тиімді мәндер кеңістігі болатынын ескерді. Ұқсас есептер Дж.Сориа мен П.Традацет жұмысында Харди және Харди типтес операторлар үшін зерттелген [1]. Авторлар сол ғалымдардың кейбір нәтижелерінің аналогын Марцинкевич кеңістіктеріндегі Гильберт түрлендіруі үшін қолданған.

Kiлm сөздер: алмастыру-инвариантты банах кеңістігі, Гильберт түрлендіруі, Кальдерон операторы, Марцинкевич кеңістігі.

Н.Т. Бекбаев, К.С. Туленов

\section{Об ограниченности преобразования Гильберта в пространствах Марцинкевича}

В статье исследованы свойства ограниченности классического (сингулярного) преобразования Гильберта

$$
(\mathcal{H} f)(t)=p \cdot v \cdot \frac{1}{\pi} \int_{\mathbb{R}} \frac{f(s)}{t-s} d s,
$$


действующего на пространствах Марцинкевича. Преобразование Гильберта является линейным оператором, возникающим при изучении граничных значений вещественной и мнимой частей аналитических функций. Поэтому вопросы, связанные с $\mathcal{H}$, возникают из-за использования сложных методов в анализе Фурье. В частности, $\mathcal{H}$ играет решающую роль в вопросах сходимости по норме рядов и интегралов Фурье. Авторами статьи рассмотрен вопрос о том, каково будет минимальное перестановочноинвариантное пространство банаховых функций $F(\mathbb{R})$ для того, чтобы $\mathcal{H}: M_{\phi}(\mathbb{R}) \rightarrow F(\mathbb{R})$ был ограниченным в фиксированном пространстве Марцинкевича $M_{\phi}(\mathbb{R})$. Кроме того, показаны существование перестановочно-инвариантной области значений функций в пространствах Марцинкевича, ссылка на пространство $F(\mathbb{R})$ как оптимальное пространство для ограниченного оператора $\mathcal{H}$ в области определения $M_{\phi}(\mathbb{R}) \subseteq \Lambda_{\varphi_{0}}(\mathbb{R})$. Подобные конструкции были изучены Дж. Сориа и П.Традацетом для операторов Харди и типа Харди [1]. Авторами использованы их идеи для получения аналогов некоторых их результатов для оператора $\mathcal{H}$ в пространствах Марцинкевича.

Ключевые слова: перестановочно-инвариантное банахово пространство, преобразование Гильберта, оператор Кальдерона, пространство Марцинкевича. 